Brit. J. industra. Med., 1964, 21, 280.

\title{
SOME TOXIC EFFECTS OF DIELDRIN IN RATS
}

\author{
BY \\ J. M. BARNES and D. F. HEATH \\ From the Toxicology Research Unit, Medical Research Council Laboratories, Carshalton,
Surrey
}

(RECEIVED FOR PUBLICATION MAY 1, 1964)

The oral toxicity of dieldrin in rats depends upon its concentration in the vehicle (arachis oil). It is increased by a previous restriction of diet, leading to a loss of weight. Two equal doses given within three weeks of each other are more toxic than the sum of the two given as a single dose.

Dieldrin is a technical product containing $85 \%$ of H.E.O.D., the approved name for 1,2,3,4,10,10,hexachloro-exo-6,7-epoxy-1,4,4a, $5,6,7,8,8 \mathrm{a}$-octahydro-exo-1,4, endo-5,8,-dimethanonaphthalene. The remaining $15 \%$ of the technical product consists of active isomeric compounds. Dieldrin is a powerful insecticide that has been extensively used in agriculture, food storage, and public health work. Where men have been exposed to dieldrin over long periods in house spraying programmes many cases of poisoning have been reported (Hayes, 1959).

Dieldrin acts as an acute convulsive poison in man and laboratory animals. Although the manifestations of poisoning may be severe and dramatic, there have been very few human fatalities, and no irreversible neurological sequelae have so far been reported.

Most cases of occupational poisoning in man have followed fairly long periods of exposure, and in some cases convulsions have recurred some days or weeks after exposure had ceased (Hayes, 1959). Thus dieldrin appears to be a cumulative poison with prolonged effects.

Recent work on the metabolism of dieldrin (Heath and Vandekar, 1964) provides a possible explanation for the behaviour of dieldrin as a poison in man. These same observations also provide an explanation for some experiments on laboratory animals carried out about five years ago, which are the subject of this paper.

As a single dose given by mouth in a solution in edible oil, dieldrin has been reported to have an $\mathrm{LD}_{50}$ of $87 \mathrm{mg} . / \mathrm{kg}$. (Lehmann, 1951), $65 \mathrm{mg} . / \mathrm{kg}$. (Klimmer, 1955), and $38 \mathrm{mg} . / \mathrm{kg}$. (Treon and Cleveland, 1955). These differences are probably accounted for partly by variations in the quality of the material tested and partly by differences in the strain, sex, and ages of the rats. However, the important feature of dieldrin tested in this way is that, as recorded first by Lehmann (1951), death after a single dose may be delayed up to six days or longer.

The experiments to be described here record the influence of the concentration of solution used on the pattern of poisoning and the effect of previous semi-starvation on susceptibility, and also the fact that rats that have survived one dose of dieldrin remain much more sensitive than normal rats to a second dose given up to three weeks later.

\section{Materials and Methods}

Technical dieldrin supplied by the Shell Petroleum Company was dissolved in arachis oil and given to unanaesthetized rats by stomach tube. Albino rats, male and female, ranging in weight from 140 to $250 \mathrm{~g}$. were used. They had access to water and food (M.R.C. diet 41B cubes) at all times except when specifically stated otherwise. The rats were under observation for the first four to six hours after dosing and were observed daily for the next seven to 10 days except on Saturdays and Sundays when deaths only were recorded. In most experiments the animals were weighed several times during the seven to 10 days following dosing. Their general behaviour was recorded.

\section{Results}

Reactions to a Single Dose.-The $\mathrm{LD}_{50}$ for a single oral dose was found to be $50.8 \mathrm{mg}$. $/ \mathrm{kg}$. (Table 1) by probit analysis (Finney, 1947). For most later 
TABLE 1

LD $_{\text {so }}$ IN FEMALE RATS OF DIELDRIN GIVEN AS A SINGLE ORAL DOSE IN $4 \%$ SOLUTION IN ARACHIS OIL

\begin{tabular}{c|c|c}
\hline Dose (mg./kg.) & No. of Rats & No. Dead \\
\hline 160 & 24 & 21 \\
80 & 32 & 22 \\
40 & 50 & 21 \\
20 & 32 & 4
\end{tabular}

Probit $=(2.53 \pm 0.43) \log ($ dose $)+0.69$

$\mathrm{LD}_{\mathrm{so}}=50.8 \mathrm{mg} . \mathrm{kg}$.

Fiducial limits are $41 \cdot 3-62.5 \mathrm{mg} . / \mathrm{kg}$.

The rats were observed for 14 days.

experiments the dose was $40 \mathrm{mg} . / \mathrm{kg}$. given as a $4 \%$ solution in arachis oil. After this dose most rats became tense after 30 to $60 \mathrm{~min}$. and had one or more convulsions during the next hour or so. Of the rats that died, about half did so in less than 18 hours. The remaining deaths were scattered over the following seven days (Heath and Vandekar, 1964, Table 2). During this period many of the animals remained tense and irritable if handled or disturbed, and occasionally a convulsion was observed. Although there was no significant difference in the sensitivity of the sexes to dieldrin, the female rats were always more irritable than the males. The majority of the rats surviving the first 24 hours after a dose of $40 \mathrm{mg}$. $/ \mathrm{kg}$. dieldrin lost weight progressively for the next four days but had begun to put on weight by the seventh day.

Effect of Weight Loss on Mortality.-Susceptibility to dieldrin was correlated with loss of weight. Of the animals for which data are available, it was found that, of the 13 which lost $25 \mathrm{~g}$. or more by the fourth day, eight died whereas none of the 18 rats that lost only 15 to $20 \mathrm{~g}$. in the same period died up to the eighth day.

A similar effect was observed when rats were made to lose weight by restricting their diet before giving

TABLE 2

EFFECTS OF RESTRICTING DIET ON THE ORAL TOXICITY OF DIELDRIN GIVEN AS A $4 \%$ SOLUTION IN ARACHIS OIL AND ITS RELATION TO THE REDUCTION IN BODY WEIGHT

\begin{tabular}{|c|c|c|c|c|}
\hline \multirow{2}{*}{\multicolumn{2}{|c|}{ Treatment }} & \multicolumn{2}{|c|}{ Mortality } & \multirow{2}{*}{$\begin{array}{l}\text { Weight } \\
\text { Deficit }\end{array}$} \\
\hline & & To $24 \mathrm{hr}$. & To 8 days & \\
\hline \multicolumn{2}{|c|}{ Controls } & $2 / 28$ & $5 / 28$ & 0 \\
\hline $\begin{array}{c}\begin{array}{c}\text { Half } \\
\text { diet } \\
\text { (days) }\end{array} \\
\end{array}$ & $\begin{array}{l}\text { Recovery } \\
\text { period } \\
\text { (days) }\end{array}$ & & & \\
\hline $\begin{array}{l}\mathbf{6} \\
\mathbf{6} \\
\mathbf{6} \\
\mathbf{6}\end{array}$ & $\begin{array}{l}0 \\
1 \\
4 \\
7\end{array}$ & $\begin{array}{l}8 / 10 \\
7 / 12 \\
3 / 12 \\
1 / 6\end{array}$ & $\begin{array}{c}8 / 10 \\
10 / 12 \\
9 / 12 \\
5 / 6\end{array}$ & $\begin{array}{l}21 \\
18 \\
12 \\
9\end{array}$ \\
\hline
\end{tabular}

*The weight deficit is expressed as a percentage of the weight of the controls at the time of dosing. dieldrin. The mortality was significantly higher in the partially starved groups (Table 2), and the effect was greater the greater the reduction in weight relative to the controls. (Absolutely, some rats gained a little weight, but much less than the controls.)

Effect of Concentration.-The response of rats to the same dose of dieldrin varied with the concentration of the solution used to administer the dose. From Table 3 it will be seen that not only was

TABLE 3

EFFECT OF CONCENTRATION ON THE TOXICITY OF SOLUTIONS OF DIELDRIN TO RATS

\begin{tabular}{c|c|c|c|c|}
\hline $\begin{array}{c}\text { Dose } \\
\text { (mg./kg.) }\end{array}$ & $\begin{array}{c}\text { Concentration } \\
\text { of Solution } \\
(\% \mathbf{w} / \mathbf{v})\end{array}$ & Mortality & \multicolumn{2}{|c|}{ Time of Death } \\
\cline { 2 - 5 } & 1 & $\langle 24 \mathrm{hr}$. & $>24 \mathrm{hr}$. \\
\hline 80 & 2 & $4 / 8$ & 0 & 4 \\
& 4 & $5 / 8$ & 0 & 5 \\
60 & 8 & $7 / 8$ & 5 & 2 \\
& 1 & $5 / 8$ & 5 & 0 \\
40 & 8 & $2 / 8$ & 1 & 1 \\
& 1 & $7 / 8$ & 3 & 3 \\
& 4 & $0 / 8$ & 7 & 0 \\
& 8 & $2 / 8$ & 2 & 0 \\
\hline
\end{tabular}

Dieldrin was given as a single dose by mouth in solution in arachis oil to female rats $175-200 \mathrm{~g}$. body weight.

the mortality higher when the concentration was greater but the rats died more rapidly. Deaths were delayed for up to eight days when dilute solutions were used.

Effect of a Second Dose.-Female rats were given $40 \mathrm{mg} . / \mathrm{kg}$. by mouth in a $4 \%$ solution in arachis oil and a second dose at various times later. The results of those experiments in which the second dose equalled the first are summarized in Table 4.

The total dose given to the rats receiving two doses was $80 \mathrm{mg} . / \mathrm{kg}$. From the probit equation derived from the $L D_{50}$ data in Table 1 the probit of the expected mortality at this dose and its standard error were calculated. When the second dose was

TABLE 4

EFFECT OF GIVING A SECOND DOSE OF DIELDRIN ON THE MORTALITY OF RATS SURVIVING THE FIRST DOSE

\begin{tabular}{c|c|c|c}
\hline $\begin{array}{c}\text { Second Dose Given } \\
\text { (days later) }\end{array}$ & $\begin{array}{c}\text { No. of } \\
\text { Experiments }\end{array}$ & $\begin{array}{c}\text { No. of } \\
\text { Rats }\end{array}$ & Deaths \\
\hline $\begin{array}{c}1-7 \\
8-14\end{array}$ & 8 & 44 & 43 \\
$15-21$ & 4 & 24 & 20 \\
\hline Female rats* & 3 & 19 & 12 \\
\hline \begin{tabular}{l} 
Dieldrin \\
\hline
\end{tabular} & $\begin{array}{c}175-200 \text { g. body weight } \\
\text { 40 mg./kg. as a 4\% solution in arachis oil }\end{array}$ \\
\hline
\end{tabular}

*The rats were given dieldrin by mouth at the beginning of the experiment and at the stated times later. 
given within a week of the first the observed mortality was $97.5 \%$, very much greater $(\mathrm{P}<<0.001)$ than the expected mortality $(69 \%)$.

When the second dose was given more than one week after the first dose a correction must be applied to allow for the deaths that had already taken place from the effects of the first dose. The expected mortality from the first dose was $37 \%$. Thus the 24 rats given a second dose represented the survivors of the first dose, i.e., 24 rats represent $63 \%$ of the rats used in the double dosing experiments. Thus the total of rats used was $24+13=37$ rats and the total number of deaths was $20+13$ $=33$. The percentage mortality was therefore $89 \%$. Similarly, when the second dose was given in the third week the percentage mortality was $77 \%$. These estimates may be a little in error because there is variance in the expected mortality from the first dose, but it can be shown that this is largely selfcancelling in the calculation. For example, if, improbably, only $20 \%$ died from the first dose, the percentage deaths from both doses become $87 \%$ and $71 \%$. Both percentage mortalities are significantly greater than those expected from a single dose of $80 \mathrm{mg}$. $/ \mathrm{kg}$. ( $\mathrm{P}<<0.001$, and $0.01>P>0.001)$. By the third week about half the dieldrin from the first dose will have been excreted (Heath and Vandekar, 1964) so a more relevant comparison would be with a total single dose of $60 \mathrm{mg}$. $/ \mathrm{kg}$., which has an expected mortality of $58 \%$.

A smaller number of experiments showed that when the second dose was only $20 \mathrm{mg} . / \mathrm{kg}$., given within seven days of a dose of $40 \mathrm{mg} . / \mathrm{kg}$., the mortality was greater than expected.

\section{Discussion}

These observations on rats receiving dieldrin by mouth underline the prolonged action of this substance in the animal, but no explanation of the phenomena could be provided in the absence of more information on the behaviour of dieldrin after it had been absorbed.

The metabolic studies described by Heath and Vandekar (1964) provide this information. The results are discussed in detail in that paper and lead to the conclusion that a large proportion of the first dose of dieldrin is laid down in the fat and slowly released into the blood-stream during the period when the animal is sensitive to the second dose.

We are grateful to Dr. M. Vandekar for providing much of the data from which Table 1 has been compiled, and to Mr. C. R. Kennedy for technical assistance.

\section{REFERENCES} Finney, D. J. (1947). Probit Analysis, Cambridge University. $21,269$. Heath, D. F., and Vandekar, M. (1964). Brit. J. industr.

Klimmer, O. R. (1955). Arch. exp. Path. Pharmak., 227, 183.

Lehmann, A. J. (1951). Quart. Bull. Ass. Food Drug Off., 15, 130. Treon, J. G., and Cleveland, F. P. (1955). J. agric. Food Chem., 3, 402. 